\title{
Crustal structure in the northwestern part of the Izu collision zone in central Japan
}

Ryuta Arai ${ }^{1,2,3^{*}}$ and Takaya Iwasaki ${ }^{1}$

\begin{abstract}
The Izu-Bonin arc (IBA) has been colliding with the Honshu arc since the middle Miocene, which together form the active Izu arc-arc collision zone (ICZ) in central Japan. To understand the entire collisional system, we have used refraction/wide-angle reflection data to model velocity structures of the Honshu arc, northwest of the ICZ. The seismic data indicate that the upper $4-\mathrm{km}$ crust of the Honshu arc consists of a horizontally homogenous layer with $P$ wave velocity (Vp) of 5.6 to $6.0 \mathrm{~km} / \mathrm{s}$ and $S$ wave velocity (Vs) of 3.4 to $3.7 \mathrm{~km} / \mathrm{s}$. This uniformity is in contrast with the heterogeneous structure further south, where the accreted crustal blocks of the IBA are bounded by dipping collisional boundaries. These contrasting structures suggest that crustal shorting caused by the arc-arc collision has been mostly accommodated within the IBA by reverse faulting along collisional boundaries, with the Honshu arc undergoing relatively little crustal deformation. The high-velocity body of the Kofu granitic complex (KGC), generated by partial melting of the subducted IBA crust, is mostly situated at $>4-\mathrm{km}$ depths but shallows significantly just beneath the Kofu Basin. This structural change implies that most of the KGC magma had erupted from just beneath the Kofu Basin.
\end{abstract}

Keywords: Izu collision zone; Izu-Bonin arc; Honshu arc; Arc-arc collision; Kofu granitic complex; Seismic wave velocity structure

\section{Background}

Understanding the processes involved in arc-arc and arc-continent collision is a critical step in determining the evolution and fate of crust that is generated in original island arcs. It is still debated whether arc crust is subducted into the mantle or is ultimately incorporated into continents, thus contributing to their growth. Although the accretion of magmatic arcs is considered a primary mechanism by which the continents have grown over most of Earth's history (Hamilton 1981; Card 1990), the tectonic processes responsible, such as accretionary wedge development and obduction/underplating of the arc crust, are poorly documented, especially in arc-arc collision settings.

The Izu collision zone (ICZ) in central Japan is a globally unique active arc-arc collision zone that provides an excellent research field for studying how island arcs evolve during collision and subduction. The Izu-Bonin arc (IBA),

\footnotetext{
* Correspondence: ryuta@jamstec.go.jp

${ }^{1}$ Earthquake Research Institute, University of Tokyo, 1-1-1 Yayoi, Bunkyo-ku,

Tokyo 113-0032, Japan

${ }^{2}$ Geology and Geophysics, SOEST, University of Hawaii at Manoa, 1680

East-West Road, POST821, Honolulu, HI 96814, USA

Full list of author information is available at the end of the article
}

the intra-oceanic volcanic arc developed in the eastern part of the Philippine Sea (PHS) plate, has been undergoing collision with the more northerly Honshu arc since the middle Miocene (Figure 1). During this process, several crustal fragments derived from the IBA, namely the Koma Mountains, Misaka Mountains, Tanzawa Mountains, and Izu Peninsula, have accreted onto the Honshu arc (e.g., Aoike 1999). Subduction zones have also developed on both sides of the ICZ, associated with convergence between the PHS and Eurasian plates at a rate of approximately $3 \mathrm{~cm} /$ year (Seno et al. 1993; Figure 1b). Recent seismic tomography has imaged a northward-dipping high-velocity body that extends beneath the ICZ to a depth of $>100 \mathrm{~km}$, suggesting that the IBA crust is subducting beneath the Honshu arc (Kamiya and Kobayashi 2007; Matsubara et al. 2008; Nakajima et al. 2009).

Recent active-source seismic experiments have succeeded in revealing fine-scale collisional structures in the ICZ (Figure 1b). In the eastern part of the collision zone, the upper part of the IBA crust (Tanzawa block) delaminated from its subducted lower part and formed an uptilted accretionary wedge (Sato et al. 2005; Arai et al. 2009). From reflection analysis of the western profile, Sato 


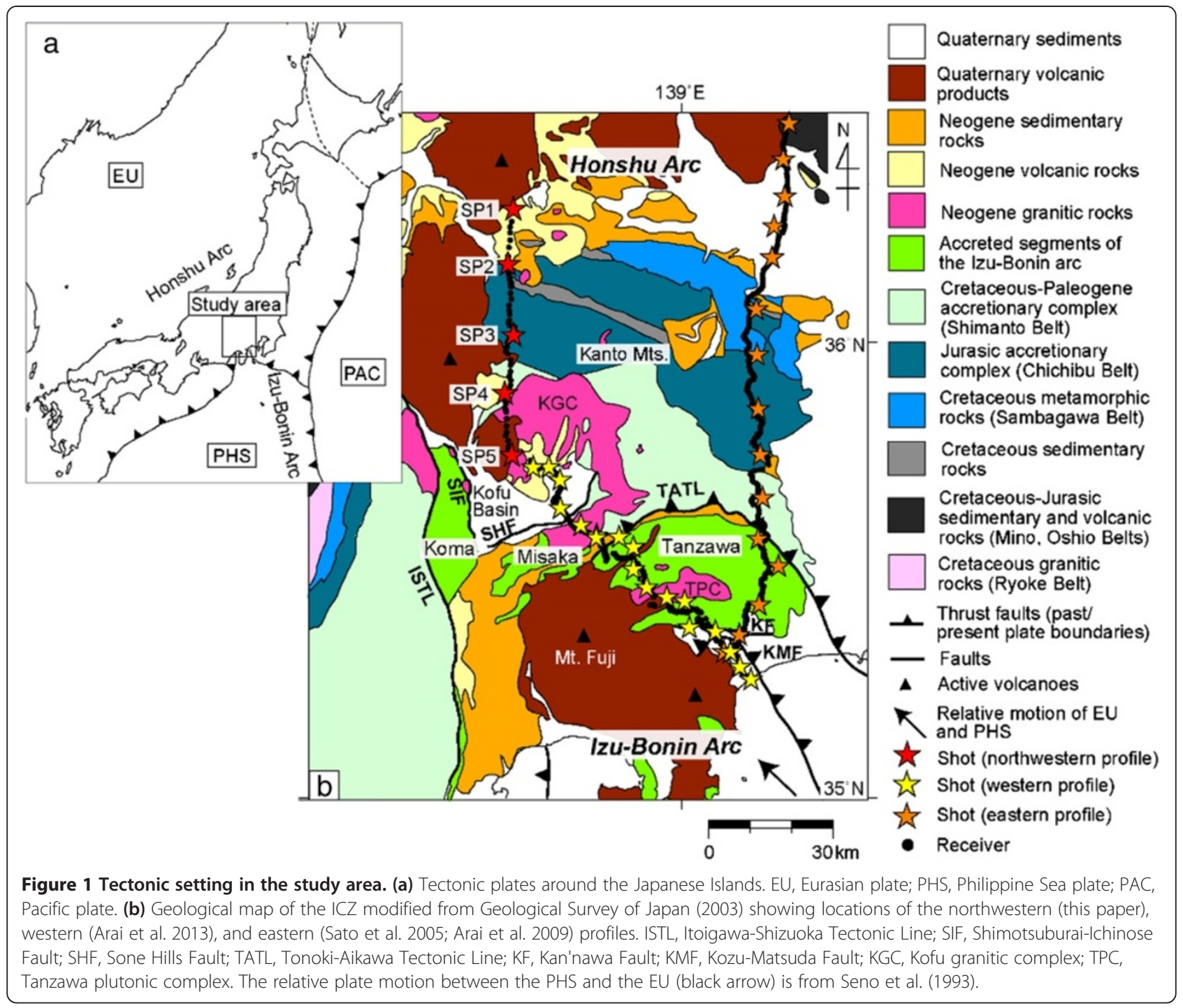

et al. (2006) found an aseismic slab beneath the Misaka and Tanzawa blocks at a depth of 30 to $35 \mathrm{~km}$, along which the IBA middle/lower crust subducts (Arai et al. 2009). Refraction analysis using the same data set (Arai et al. 2013) revealed that the overall geometry of the collisional boundaries is that of a doubly vergent system (e.g., Willett et al. 1993), which is characterized by inward-dipping reverse faults on both sides. Arai et al. (2013) also showed that Miocene granitic plutons with high seismic velocities that intrude into the Honshu arc crust and accreted crustal blocks of the IBA (Tanzawa block) form the Kofu granitic complex (KGC) and the Tanzawa plutonic complex (TPC), respectively. Petrological investigations have suggested that these intrusive rocks formed by syncollisional magmatism of the IBA crust that subducted beneath the Honshu arc (Saito et al. 2007; Tamura et al. 2010; Tani et al. 2010).

Identifying the detailed structures of the Honshu arc and IBA is inevitably important in developing an understanding of the entire collision system. Although the abovementioned studies focused on the internal structure of the accreted IBA crust, little equivalent evidence relating to the more northerly Honshu arc currently exists. Seismic refraction/wide-angle reflection data collected by the Research Group for Explosion Seismology (RGES) in 1982 are suitable to address this issue, as its $60-\mathrm{km}$ profile line was orientated northward from the collision front to the Honshu arc side (Figure 1b). Furthermore, this seismic line is located $60 \mathrm{~km}$ west of the eastern profile (Sato et al. 2005; Arai et al. 2009) and almost connects at its southern end to the western profile (Sato et al. 2006; Arai et al. 2013). This data set allowed Sasatani et al. (1990) to infer the velocity structure of the Honshu arc by a time-term method and amplitude evaluation of first arrivals. Although they provided some aspects of the Honshu arc crustal structure, including the existence of a deep reflector, the seismic data were not fully interpreted in the context of 
the Honshu arc and IBA collision process. In this paper, we provide a more rigorous structural model that is based on travel time analysis and amplitude modeling using a ray tracing method. Integrated interpretations for these models, together with results from recent active-source profiles in the surrounding area, provide new constraints on the structure around the collision zone, including the Honshu arc crust and the subsurface distribution of granitic plutons.

\section{Tectonic setting}

The Japanese Islands consist of several island arcs located on the eastern side of the Asian continent (Figure 1a). The NE Japan arc, which consists of western Hokkaido and northern Honshu, overrides the Pacific (PA) plate. The SW Japan arc consists of western Honshu, Shikoku, and Kyushu, beneath which the PHS plate is subducting. These arcs are considered to have been located on the eastern flank of the Asian continent during most of the Mesozoic to early Miocene time and were rotated to their present locations during the Miocene back-arc opening of the Sea of Japan (Otofuji et al. 1985).

The Kanto Mountains of the Honshu arc consist of preNeogene accretionary prisms in the outer zone, represented by the Sambagawa metamorphic belt, the Chichibu belt, and the Shimanto belt, which are bound to the west by the Itoigawa-Shizuoka Tectonic Line (ISTL) (Taira et al. 1989; Kano et al. 1990; Suzuki 2002; Figure 1b). The Sambagawa metamorphic belt consists of high-pressure metamorphic rocks of Cretaceous age. The Chichibu belt is mainly composed of Jurassic sandstone and mudstone, with subsidiary chert and limestone. The Shimanto belt is similar to the Chichibu belt but is instead characterized by strata of Cretaceous to Paleogene age.

The IBA, the intra-oceanic volcanic arc located south of the Honshu arc, developed on the eastern part of the PHS following the initiation of subduction of the PA. The IBA began to separate from the Kyushu-Palau Ridge at $25 \mathrm{Ma}$, forming a back-arc basin (Shikoku Basin) south of Japan (Okino et al. 1999). At almost the same time that back-arc spreading ceased (about $15 \mathrm{Ma}$ ), the IBA started to collide against the Honshu arc due to the northwestward movement of the PHS plate and back-arc opening of the Sea of Japan (Takahashi and Saito 1997). Convergence between the PHS and the overlying continental plate is approximately aligned with the strike direction of the IBA (e.g., Seno et al. 1993), which has resulted in focused collision tectonics occurring in a small area over a long time.

The ICZ has been intensively studied over the past few decades, especially from geological approaches (e.g., Sugimura 1972; Amano 1991; Koyama 1991; Taira et al. 1998; Aoike 1999). These studies have suggested that the Koma Mountains, Misaka Mountains, Tanzawa Mountains, and Izu Peninsula are crustal blocks that were derived from the IBA and subsequently accreted onto the Honshu arc during the collision process. Based on accumulation ages of trough fills along the segment boundaries, Aoike (1999) estimated the accretion ages of the Koma, Misaka, Tanzawa, and Izu blocks to be 17 to 15,15 to $12,8.5$ to 3.5 , and 2.2 to $0.5 \mathrm{Ma}$, respectively. These crustal blocks are separated by tectonic boundaries represented by the Shimotsuburai-Ichinose Fault (SIF), Sone Hills Fault (SHF), Tonoki-Aikawa Tectonic Line (TATL), Kan'nawa Fault (KF), and Kozu-Matsuda Fault (KMF) (Figure 1b).

The Kofu Basin is a key site for understanding the collisional structure of the ICZ. The basin is located southwest of the Kanto Mountains (Honshu arc) and is adjacent to the Misaka block at its southern end, being separated from the latter by the SHF (Figure 1b). The Koma block is located on the western side of the basin and is bounded by the SIF (Figure 1b). Previous studies suggest that the basin is filled with Pliocene lavas, pyroclastic rocks, and Pliocene to Quaternary alluvium (Umino 1991). However, a lack of geological/geophysical information about the deeper structure, especially regarding whether the subbasin crust originated from the Honshu arc or the IBA, has hindered our understanding of the collisional style between these two arcs.

Regional exposures of granitic rocks are another distinct feature in the ICZ, with the KGC outcropping over a wide area around the Kofu Basin. Petrological studies have shown that these plutons were emplaced at 16.8 to 10.6 Ma, which is almost coincident with the onset of the collision of the IBA (Saito et al. 2007). In addition, the TPC, which intrudes the center of the Tanzawa Mountains (Kawate and Arima 1998), mainly consists of granite and tonalite that are thought to have been generated by partial melting of the middle/lower crust of the Honshu arc and IBA (Saito et al. 2007; Tamura et al. 2010; Tani et al. 2010).

\section{Methods}

A seismic experiment carried out on the western flank of the Kanto Mountains in 1982 (Research Group for Explosion Seismology 1986) utilized five dynamite shots $(300$ to $500 \mathrm{~kg}$ ) and 61 seismic stations on a $60-\mathrm{km}$-long profile (Figure 1b). The sampling rate for all instruments was $100 \mathrm{~Hz}$, and examples of the seismic records are given in Figure 2. The quality of the data is good, with $P$ wave first arrivals of every shot observed along the entire profile. The apparent velocities of the $P$ wave first arrivals are almost uniform, with no significant discontinuities or undulations over the whole profile, indicating that the upper crustal level has little lateral velocity variation. We can also recognize clear $S$ wave arrivals, which provide additional constraints for the interpretation of rock compositions (SP1 and SP3 in Figure 2). Deep crustal structure 

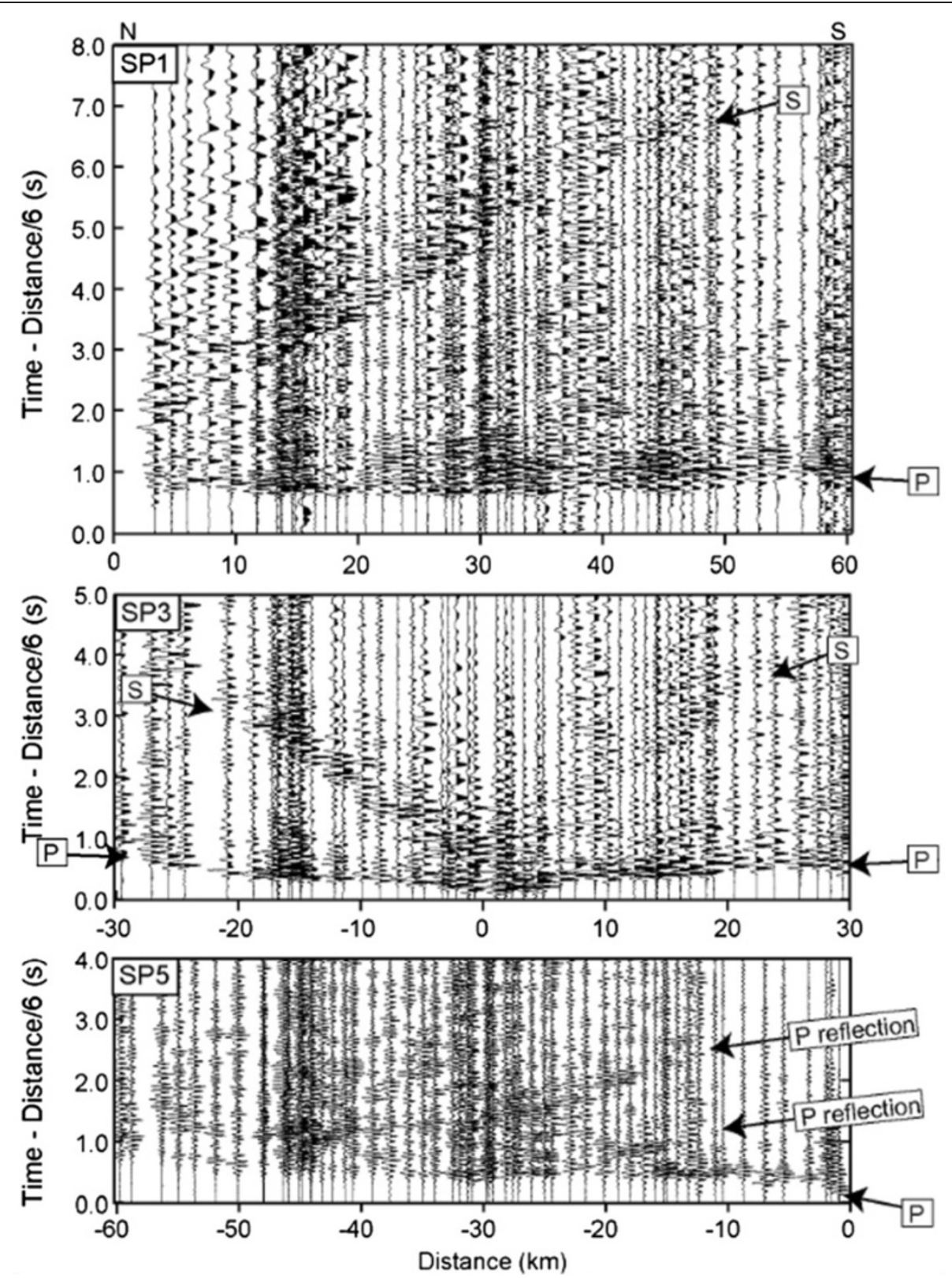

Figure 2 Seismic records of SP1 (top), SP3 (middle), and SP5 (bottom). Each trace is normalized by its maximum amplitude. Reduction velocity is $6 \mathrm{~km} / \mathrm{s}$. A 1- to 15-Hz band-pass filter is applied for SP1 and SP3. A 10- to 20-Hz band-pass filter is applied for SP5.

was modeled using travel times and the amplitude of $P$ wave reflections (SP5 in Figure 2).

We constructed $P$ and $S$ wave velocity models by employing forward modeling using a ray tracing method (Iwasaki 1988; Červený and Pšenčík 1983). The $P$ wave velocity model was constructed from both first arrivals and reflected waves by using travel time and amplitude calculations (Figure 3a). We used the velocity model by Arai et al. (2009) as an initial model for this analysis, which covers the eastern part of the Kanto Mountains. Then, the velocities and geometry of the individual layers were modified until the model satisfactorily fit the observed data (Figures 4,5,6). The $S$ wave velocity model was constructed from $S$ wave first arrivals (Figure 7). In this case, the layer geometry of the $P$ wave velocity model remained unchanged and only the $S$ wave velocities were modified. The resulting models satisfactorily explain all of the $P$ and $S$ wave travel times within an error of $0.1 \mathrm{~s}$.

\section{Results}

The $P$ and $S$ wave velocity models that were obtained by the forward modeling are shown in Figure 3a,b, respectively, 

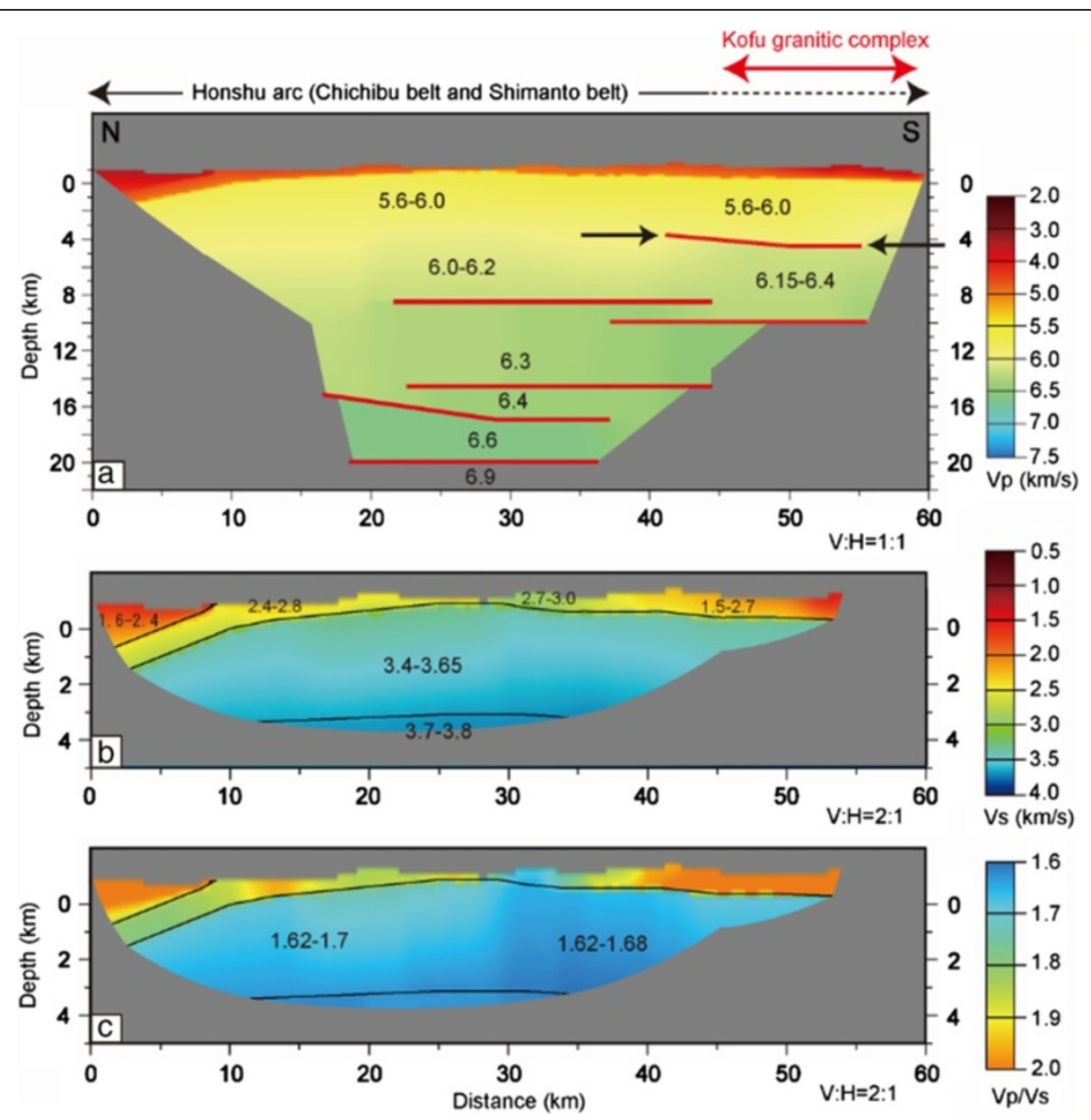

Figure 3 Final $P$ and $S$ wave velocities and Vp/Vs ratio. (a) Final $P$ wave velocity model. Surface geological information is also presented at the top of the figure. Although plutonic rocks of the Kofu granitic complex (KGC) are present at the surface in the southern part of the profile, no lateral velocity increase exists for the upper $4 \mathrm{~km}$ of crust. Black arrows highlight a reflector at 4- $\mathrm{km}$ depth, which is interpreted to be the top of the high-velocity body of the KGC (see also 'Discussion' and Figure 8). Red lines denote crustal reflectors. Grey color means no ray coverage. (b) Final $S$ wave velocity model. (c) Vp/Ns ratio calculated from (a) and (b).

with calculated $P$ wave velocity to $S$ wave velocity $(\mathrm{Vp} / \mathrm{Vs})$ ratios shown in Figure 3c. While there remains uncertainty on the details of the images due to the large spacing of the shots and receivers $(>10 \mathrm{~km}$ and approximately $1 \mathrm{~km}$, respectively), the overall structure shows the main features of the Honshu arc. $P$ and $S$ wave first arrivals provide information about wave velocities in the upper $4 \mathrm{~km}$ of crust. These velocity values are well constrained, since the almostconstant apparent velocities for first arrivals (Figure 4) require a unique model with a small uncertainty. By following a trial-and-error approach, we estimate that the velocity errors for both $P$ and $S$ waves in the upper $4 \mathrm{~km}$ of crust are less than $0.10 \mathrm{~km} / \mathrm{s}$. The deeper structure (up to $20-\mathrm{km}$ depth) is constrained by travel times and amplitudes of reflections, with estimated maximum errors of $0.40 \mathrm{~km} / \mathrm{s}$ for velocities and $0.4 \mathrm{~km}$ for layer boundary positions.

These structural models show that the Honshu arc (Chichibu belt and Shimanto belt) consists of a horizontally homogenous layer in the upper $4 \mathrm{~km}$ of crust (Figure 3a), as expected from record sections (Figure 2). The $P$ wave velocity of 5.6 to $6.0 \mathrm{~km} / \mathrm{s}$ is consistent with the findings of Sasatani et al. (1990), who used the same data set, and with the values for the eastern part of the Kanto Mountains reported by Arai et al. (2009). It is surprising that no velocity increase exists in the southern part of the profile where plutonic rocks of the KGC outcrop at the surface (Figures 3a and 8). Here, $S$ wave velocity in the upper $4 \mathrm{~km}$ of crust is estimated to be 3.4 to $3.7 \mathrm{~km} / \mathrm{s}$ (Figure $3 \mathrm{~b}$ ), and akin to $P$ wave velocity, little horizontal velocity change is observed. Consequently, a $\mathrm{Vp} / \mathrm{Vs}$ ratio of 1.6 to 1.7 occurs along the entire profile (Figure 3c). These low $\mathrm{Vp} / \mathrm{Vs}$ values are characteristic of upper continental crust and indicate that the Honshu arc crust has a high $\mathrm{SiO}_{2}$ content (Christensen 1996). A shallow reflector is located at a depth of $4 \mathrm{~km}$ in the southern part of the profile (black arrows in Figure 3a). In order to explain the shallow reflections from SP5 

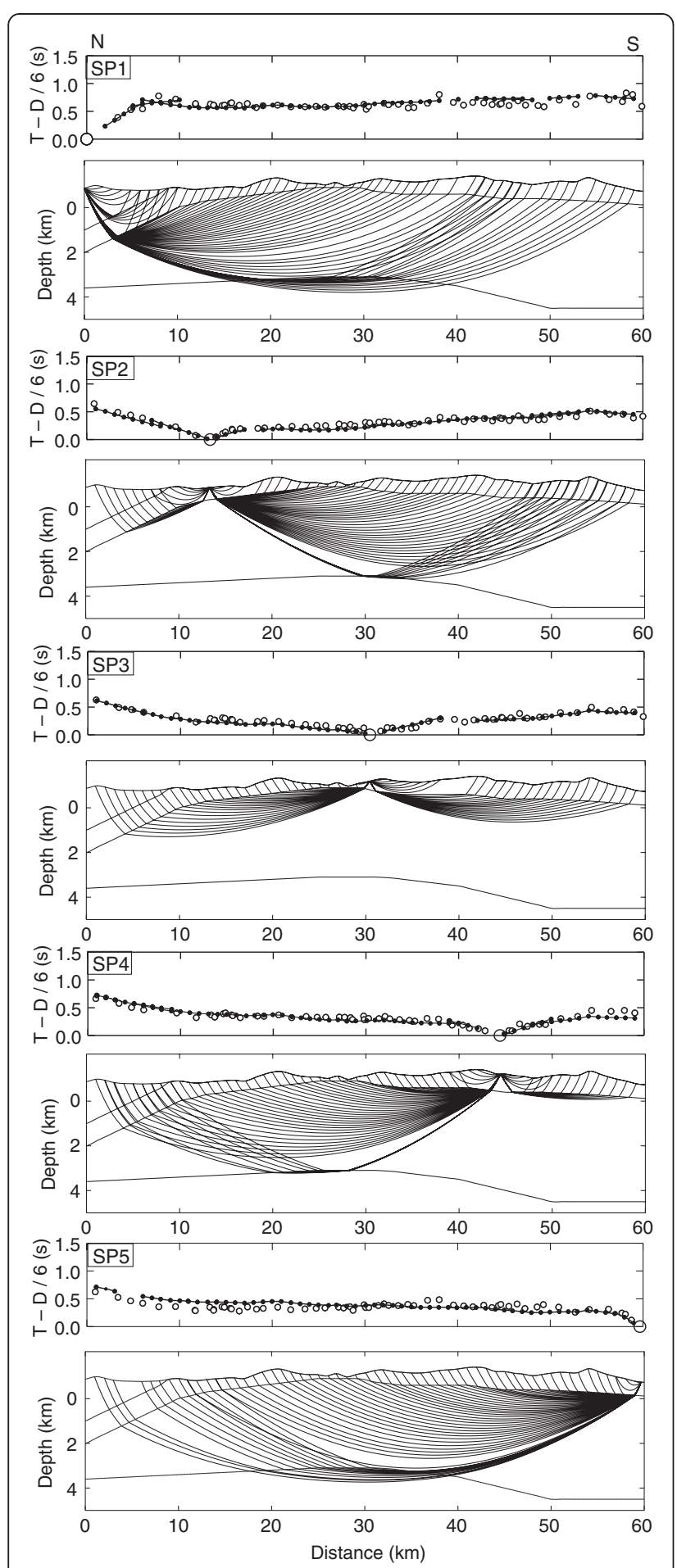

Figure 4 Comparison of observed and calculated $P$ wave first arrivals and their ray diagrams. Observed and calculated travel times are shown by open circles and black dots, respectively.

(Figure 6c), $P$ wave velocity below this reflector must be 6.15 to $6.40 \mathrm{~km} / \mathrm{s}$, which is 0.15 to $0.2 \mathrm{~km} / \mathrm{s}$ higher than the equivalent depth in the northern part (Figure 3a). These layer structures probably continue further south. The western profile by Arai et al. (2013) shows that crustal material with a $P$ wave velocity of 5.3 to $6.0 \mathrm{~km} / \mathrm{s}$, underlying the low-velocity (Vp of 2.8 to $4.1 \mathrm{~km} / \mathrm{s}$ ) sediments filling the Kofu Basin, surrounds a high-velocity body corresponding to the KGC (Figure 8) that has Vp greater than $6.0 \mathrm{~km} / \mathrm{s}$.

Although the previous study showed only one reflector in the deep crust (Sasatani et al. 1990), we identified several more reflectors with small velocity jumps at depths of 8 to $20 \mathrm{~km}$ (Figure 3a) by increasing $\mathrm{S} / \mathrm{N}$ ratios with an optimum range of a band-pass filter (Figures 2 and 5). These reflectors lie almost horizontally in our model, which differs from a northward-dipping reflector proposed by Sasatani et al. (1990). This discrepancy may result from a trade-off between the depth of a reflector and velocity above the reflector. For example, Sasatani et al. (1990) assumed that the velocity at depths of 5 to $20 \mathrm{~km}$ was 6.2 to $6.3 \mathrm{~km} / \mathrm{s}$, while we estimate an equivalent velocity of 6.2 to $6.6 \mathrm{~km} / \mathrm{s}$, which is required to account for velocity contrasts across the reflectors. We note that similar horizontal reflectors have been observed in the eastern profile (Arai et al. 2009) and from other seismic experiments on the Shimanto belt (Ito et al. 2009). Although our seismic data do not directly constrain the crustal thickness, we infer that the Moho is deeper than $20 \mathrm{~km}$ because a $P$ wave velocity of $6.9 \mathrm{~km} / \mathrm{s}$ at the deepest part of the model is too low to represent the mantle (Figure 3a), but is consistent with Honshu arc lower crust (Kodaira et al. 2002; Iidaka et al. 2004). Furthermore, a recent regional tomographic study performed by Katsumata (2010) also concluded that the crustal thickness in the study area is greater than $30 \mathrm{~km}$.

\section{Discussion}

\section{Structure of the Honshu arc}

Seismic data in the southern part of our profile indicate that the 4-km-thick upper crust, with Vp of 5.6 to $6.0 \mathrm{~km} /$ $\mathrm{s}$ and Vs of 3.4 to $3.7 \mathrm{~km} / \mathrm{s}$, corresponds to the Honshu arc (Shimanto belt) and overlies a high-velocity (6.15 to $6.4 \mathrm{~km} / \mathrm{s}$ ) body at a depth of $>4 \mathrm{~km}$. Both the $P$ and $S$ wave velocities of the Shimanto belt correlate well with those of the crustal materials beneath the Kofu Basin and Misaka block in the western profile (Arai et al. 2013). Prior to this study, the origin of the crustal materials beneath the Kofu Basin remained unknown; however, our new seismological results provide the first strong evidence that the Shimanto belt (Honshu arc) exists beneath the Kofu Basin and Misaka block (IBA) (Figure 8). This structural constraint indicates that the Misaka block obducted onto the Honshu arc.

Although our profile line crosses surface exposures of the KGC (Figure 1b), no significant velocity change is seen in the upper 4- $\mathrm{km}$ crust in this region (Figure 3). The top of the aforementioned 6.15 to $6.4 \mathrm{~km} / \mathrm{s}$ layer is at a depth of $4 \mathrm{~km}$, which is almost comparable to the top of the high-velocity body beneath the Kofu Basin further south 

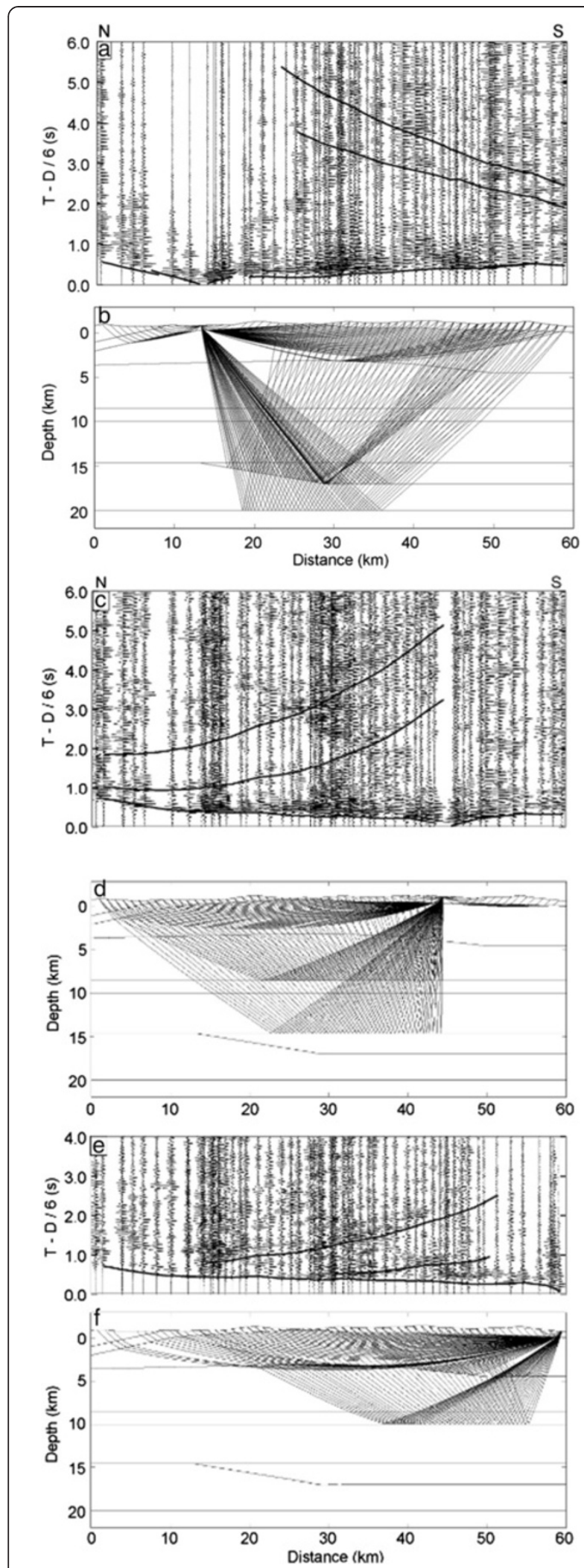

Figure $\mathbf{5}$ Comparison of observed seismic records and calculated travel times (black lines), and their ray diagrams. (a) SP2. A 10- to 20-Hz band-pass filter is applied. (b) Ray diagram for SP2. (c) SP4. A 10- to 20-Hz band-pass filter and a 3-s automatic gain control (AGC) are applied. (d) Ray diagram for SP4. (e) SP5. A 10- to 20-Hz band-pass filter is applied. (f) Ray diagram for SP5.

(Arai et al. 2013). Thus, we interpret that the 6.15 to $6.4 \mathrm{~km} / \mathrm{s}$ layer reflector also represents the main body of the KGC (Figure 8). In particular, the magma chamber supplying the KGC is probably situated below our profile at a depth greater than $4 \mathrm{~km}$, over which the Shimanto belt (with Vp of 5.6 to $6.0 \mathrm{~km} / \mathrm{s}$ ) occurs.

\section{Intrusion of the KGC and formation of the Kofu Basin}

In our model, the KGC is situated below a depth of $4 \mathrm{~km}$, whereas southeast of our profile, the KGC shallows significantly just beneath the Kofu Basin (Arai et al. 2013; see also Figure 8). This structural change suggests that a large amount of the KGC magma may have erupted from just beneath the Kofu Basin, a process that can be interpreted as having led to its the formation. This is due to the possibility of a volcanic eruption associated with a shallow magma chamber causing the volcano edifice to collapse into the empty magma reservoir, thus forming a steep, bowl-shaped depression called a caldera (e.g., Best and Christiansen 2001). However, this possibility contradicts petrological studies showing that the KGC formed at 16.8 to $10.6 \mathrm{Ma}$, which is almost coincident with the onset of collision of the IBA (Saito et al. 2007). On the other hand, drilling data in the Kofu Basin (Yamanashi Prefectural Government 2002) indicate that basin fill sediments consist of volcanic rocks younger than $8 \mathrm{Ma}$ (Mimura et al. 1994), suggesting that the Kofu Basin may have formed after the eruption of the KGC. Alternatively, the collision process itself may have contributed to the formation of the Kofu Basin. In this scenario, reverse faulting along the northernmost collisional boundary (SHF), located at the southern end of the Kofu Basin, is likely to have produced the fore-arc basin between the arc and outer-arc rise. Drilling data and seismic reflection profiles in the Kofu Basin indicate that basin fill sediments thicken toward the southwest (Yamanashi Prefectural Government 2002), suggesting that reverse faulting along the SIF at the Western end of the Kofu Basin also contributed toward the formation of the basin (Ikeda et al. 2009).

Implications for collision/subduction processes in the IBA The aforementioned simple structure of the Honshu arc (horizontally homogenous upper crust with $\mathrm{Vp}$ of 5.6 to $6.0 \mathrm{~km} / \mathrm{s}$ and Vs of 3.4 to $3.7 \mathrm{~km} / \mathrm{s}$ ) contrasts strongly with the complex structure further south, where the accreted crustal blocks of the IBA form a doubly vergent system (Figure 8 ). The significant difference across the 

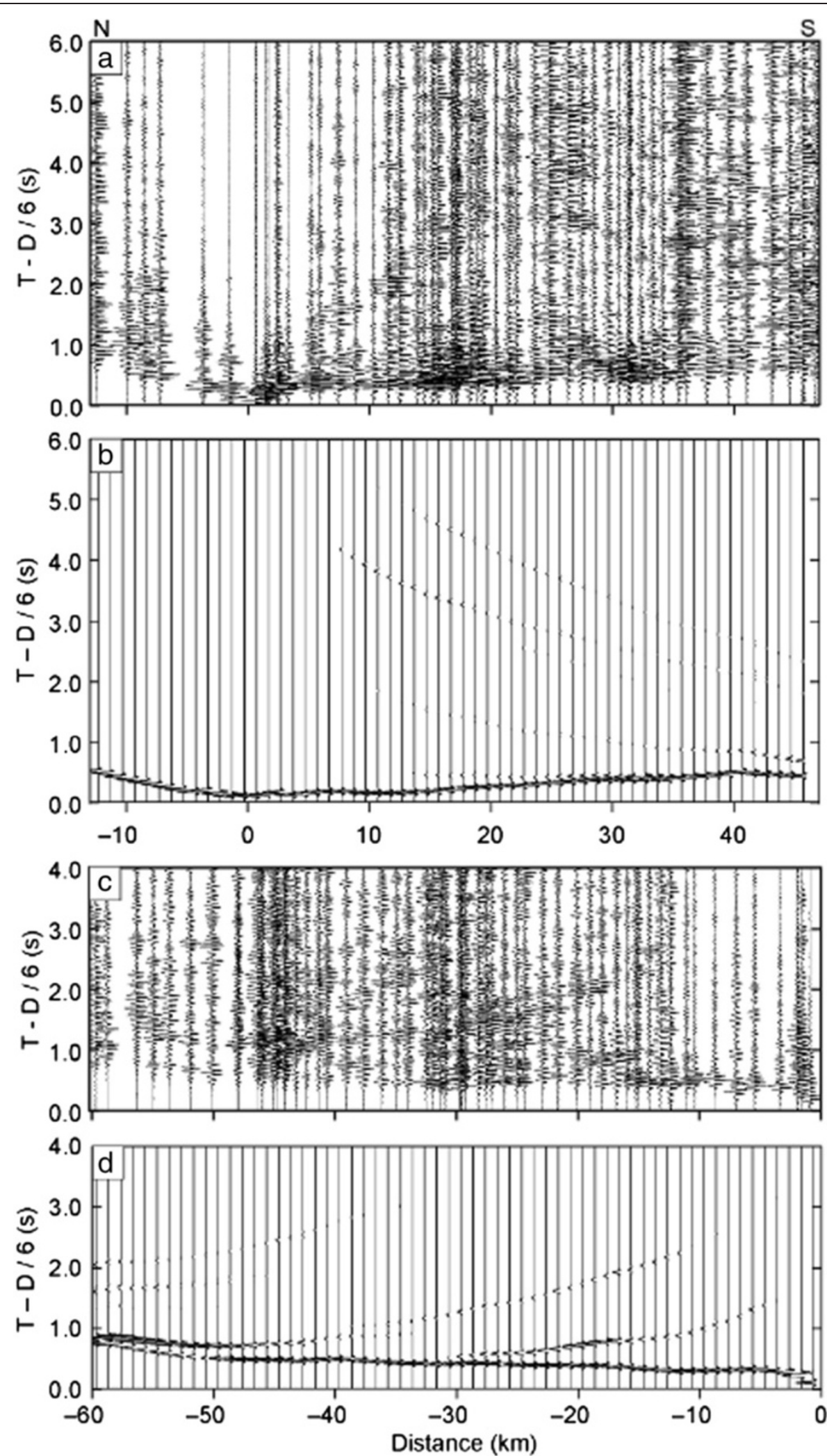

Figure 6 Comparison of observed seismic records and synthetic seismograms calculated from $P$ wave velocity model in Figure 3a. (a) Record section of SP2. (b) Synthetic seismogram of SP2. (c) Record section of SP5. (d) Synthetic seismogram of SP5. 

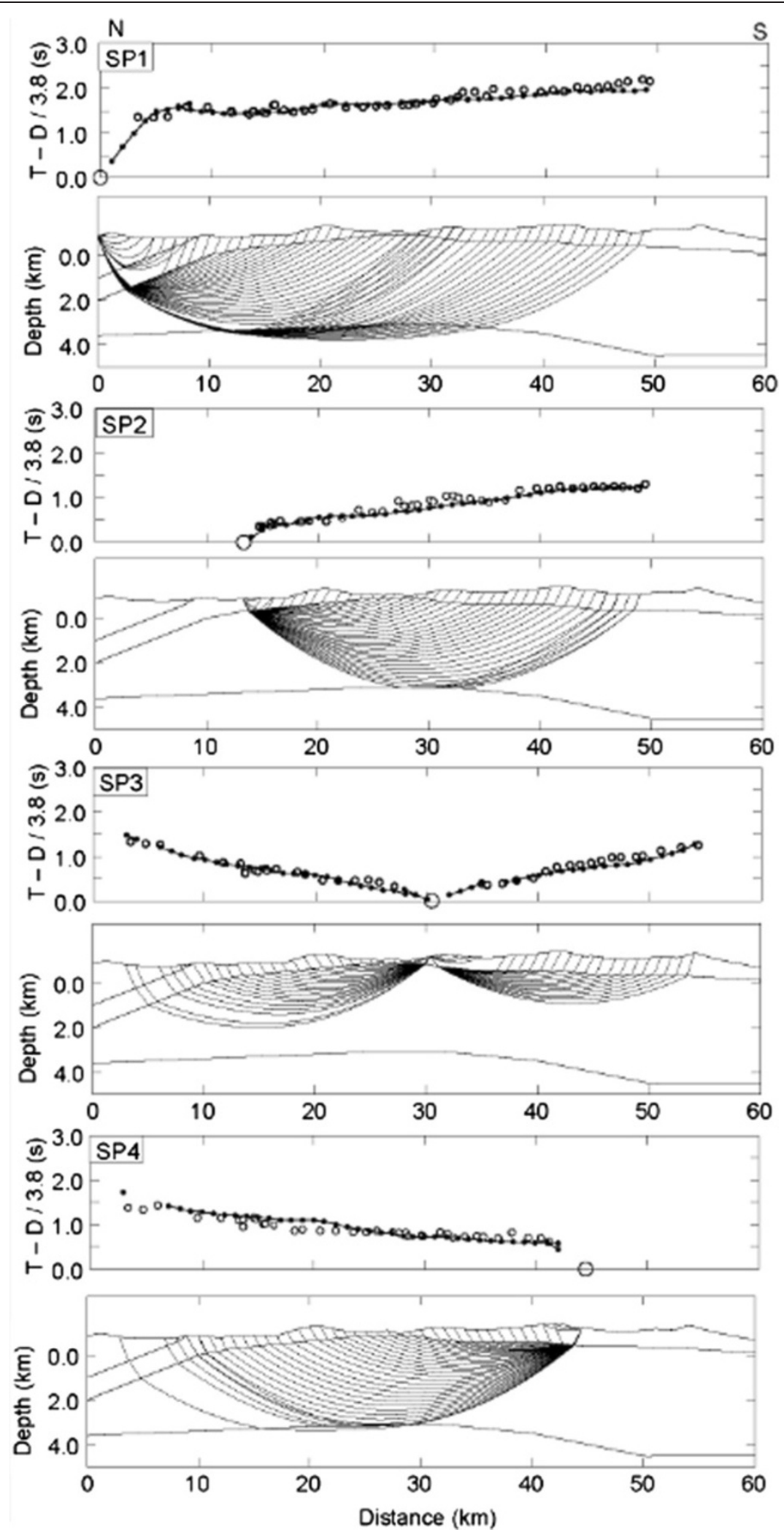

Figure 7 Comparison of observed and calculated $S$ wave first arrivals and their ray diagrams. Observed and calculated travel times are shown by open circles and black dots, respectively. 


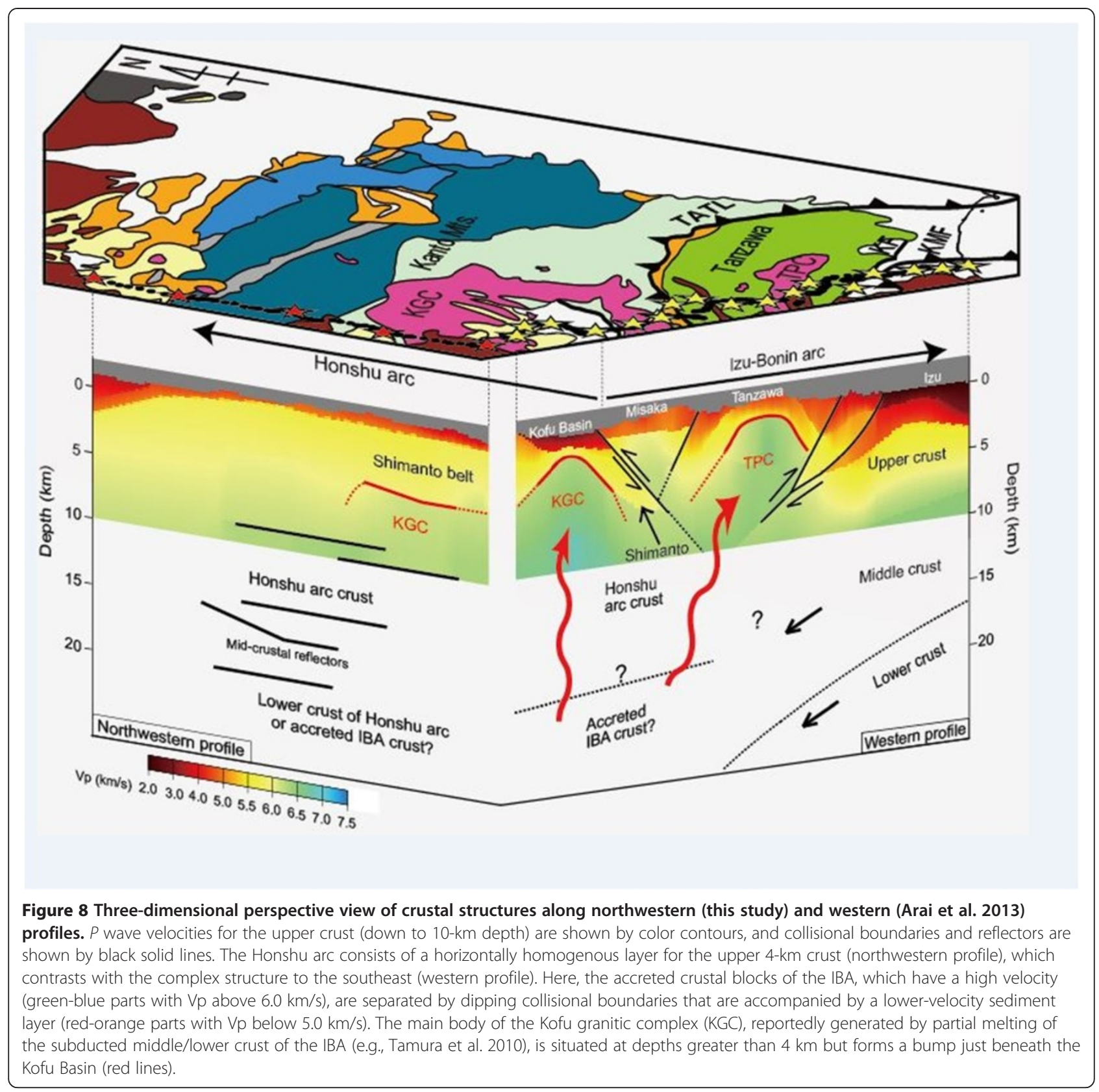

collision front indicates that crustal shorting has been accommodated only within the IBA crust (by reverse faulting along the collisional boundaries and subduction of the middle/lower crust), while the Honshu arc has undergone very little collision-related deformation.

Although the structure of the lower crust and uppermost mantle is not constrained by the northwestern profile seismic data, the velocity of $6.9 \mathrm{~km} / \mathrm{s}$ at $20-\mathrm{km}$ depth in our model (Figure 3) represents a typical value for the lower crustal part of the Honshu arc (Kodaira et al. 2002; Iidaka et al. 2004). This implies that the crustal thickness of the Honshu arc situated northwest of the collision zone is greater than $20 \mathrm{~km}$. The result is also supported by regional tomographic studies showing that the crustal thickness exceeds $30 \mathrm{~km}$ in the study area (Katsumata 2010). This is significantly deeper than the level of the Moho in southwest Japan (approximately $20 \mathrm{~km}$ ) where the PHS plate is subducting without collision (Kodaira et al. 2002; Iidaka et al. 2004; Ito et al. 2009). A possible explanation for this discrepancy comes from accretion of the IBA at the base of the Honshu arc by tectonic/magmatic underplating, where a large portion of the IBA crust has been subducting beneath the Honshu arc (Arai et al. 2009, 2013). During the subduction process, the middle/ lower crust of the IBA partially melted and produced a magmatic body at a sub-Moho level beneath the Honshu 
arc (Nakajima and Arima 1998). Following extraction from the melting zone, the felsic magma ascended and intruded into the Honshu arc crust and Tanzawa block to form the KGC and TPC, respectively (Tamura et al. 2010). Denser cumulates or restites may have remained at the bottom of the crust (Annen et al. 2006) and contributed to the growth of the Honshu arc.

\section{Conclusions}

We reevaluated refraction/wide-angle reflection data that were collected in 1982 in order to produce a new detailed crustal velocity profile of the Honshu arc crust in northwestern part of the ICZ. Our results enable a new interpretation for the collisional system of the Honshu arc and the IBA to be presented. This structural model indicates that the Honshu arc consists of a horizontally homogenous layer with $P$ and $S$ wave velocities for the upper $4 \mathrm{~km}$ of crust of 5.6 to $6.0 \mathrm{~km} / \mathrm{s}$ and 3.4 to $3.7 \mathrm{~km} / \mathrm{s}$, respectively. This uniformity contrasts with the extremely heterogeneous structure further south, where accreted crustal blocks of the IBA are separated by dipping collisional boundaries. This difference in collisional styles indicates that collision-related crustal shorting has been accommodated within the IBA crust by reverse faulting along the collisional boundaries, whereas the Honshu arc has undergone little crustal deformation. The main body of the KGC is situated at depths greater than $4 \mathrm{~km}$ but shallows significantly just beneath the Kofu Basin. This structural change implies that a large amount of the KGC magma erupted from just beneath the Kofu Basin. The seismic data also suggest that the crustal thickness of the Honshu arc exceeds $20 \mathrm{~km}$, implying that the subducted IBA crust may have thickened the crust by magmatic underplating.

\section{Competing interests}

The authors declare that they have no competing interests.

\section{Authors' contributions}

RA and TI jointly carried out seismic modeling and interpretation. RA drafted the manuscript. Both authors read and approved the final manuscript.

\section{Acknowledgements}

We are grateful to the members of the Research Group for Explosion Seismology who acquired the seismic data. This study was supported by JSPS KAKENHI (09 J09214). We used the GMT software (Wessel and Smith 1998) to draw the figures.

\section{Author details}

${ }^{1}$ Earthquake Research Institute, University of Tokyo, 1-1-1 Yayoi, Bunkyo-ku, Tokyo 113-0032, Japan. ${ }^{2}$ Geology and Geophysics, SOEST, University of Hawaii at Manoa, 1680 East-West Road, POST821, Honolulu, HI 96814, USA. ${ }^{3}$ Present address: Japan Agency for Marine-Earth Science and Technology, 3173-25 Showa-machi, Kanazawa-ku, Yokohama, Kanagawa 236-0001, Japan.

Received: 28 August 2013 Accepted: 8 December 2013

Published: 25 April 2014

\section{References}

Amano K (1991) Multiple collision tectonics of the South Fossa Magna in centra Japan. Mod Geol 15:315-329
Annen C, Blundy JD, Sparks RSJ (2006) The genesis of intermediate and silicic magmas in deep crustal hot zones. J Petrol 47:505-539

Aoike K (1999) Tectonic evolution of the Izu collision zone. Res Rep Kanagawa prefect Mus Nat Hist 9:111-151

Arai R, Iwasaki T, Sato H, Abe S, Hirata N (2009) Collision and subduction structure of the Izu-Bonin arc, central Japan, revealed by refraction/ wide-angle reflection analysis. Tectonophysics 475:438-453

Arai R, Iwasaki T, Sato H, Abe S, Hirata N (2013) Crustal structure of the Izu collision zone in central Japan from seismic refraction data. J Geophys Res Solid Earth 118:6258-6268. doi:10.1002/2013JB010532

Best MG, Christiansen EH (2001) Igneous petrology. Blackwell Science, Oxford

Card KD (1990) A review of the Superior Province of the Canadian Shield, a product of Archean accretion. Precambrian Res 48:99-156

Červený V, Pšenčík I (1983) Program package SEIS83. Charles University, Prague

Christensen NI (1996) Poisson's ratio and crustal seismology. J Geophys Res 101:3139-3156

Geological Survey of Japan (2003) Geological map of Japan 1:1,000,000, 3rd edition. 2nd CD-ROM Version, Digital Geoscience Map G-1. Geological Survey of Japan, Tsukuba

Hamilton WB (1981) Crustal evolution by arc magmatism. Philos Trans R Soc London, Ser A 301:279-291

lidaka T, Takeda T, Kurashimo E, Kawamura T, Kaneda Y, Iwasaki T (2004) Configuration of subducting Philippine Sea plate and crustal structure in the central Japan region. Tectonophysics 388:7-20

Ikeda Y, Iwasaki T, Kano K, Ito T, Sato H, Tajikara M, Kikuchi S, Higashinaka M, Kozawa T, Kawanaka T (2009) Active nappe with a high slip rate: seismic and gravity profiling across the southern part of the Itoigawa-Shizuoka Tectonic Line, central Japan. Tectonophysics 472:72-85

Ito T, Kojima Y, Kodaira S, Sato H, Kaneda Y, Iwasaki T, Kurashimo E, Tsumura N, Fujiwara A, Miyauchi T, Hirata N, Harder S, Miller K, Murata A, Yamakita S, Onishi M, Abe S, Sato T, Ikawa T (2009) Crustal structure of southwest Japan, revealed by the integrated seismic experiment Southwest Japan 2002. Tectonophysics 472:124-134

Iwasaki T (1988) Ray-tracing program for study of velocity structure by ocean bottom seismographic profiling. J Seismol Soc Jpn 41:263-266

Kamiya S, Kobayashi Y (2007) Thickness variation of the descending Philippine Sea slab and its relationship to volcanism beneath the Kanto-Tokai district, central Japan. J Geophys Res 112, B06302. doi:10.1029/2005JB004219

Kano K, Kosaka K, Murata A, Yanai S (1990) Intra-arc deformations with vertical rotation axes: the case of the pre-Middle Miocene terranes of Southwest Japan. Tectonophysics 176:333-354

Katsumata A (2010) Depth of the Moho discontinuity beneath the Japanese islands estimated by traveltime analysis. J Geophys Res 115, B04303. doi:10.1029/2008JB005864

Kawate S, Arima M (1998) Petrogenesis of the Tanzawa plutonic complex, central Japan: exposed felsic middle crust of the Izu-Bonin-Mariana arc. Island Arc 7:342-358

Kodaira S, Kurashimo E, Park J-O, Takahashi N, Nakanishi A, Miura S, Iwasaki T, Hirata N, Ito K, Kaneda Y (2002) Structural factors controlling the rupture process of a megathrust earthquake at the Nankai trough seismogenic zone. Geophys J Int 149:815-835

Koyama A (1991) Collision of the Kushigatayama block with the Honshu arc during the middle Miocene. Mod Geol 15:331-345

Matsubara M, Obara K, Kasahara K (2008) Three-dimensional P- and S-wave velocity structures beneath the Japan Islands obtained by high-density seismic stations by seismic tomography. Tectonophysics 454:86-103

Mimura K, Shibata K, Uchiumi S (1994) Volcanic activity and the K-Ar ages of Kurofuji Volcano and the adjacent volcanic rocks north of the Kofu Basin, central Japan. J Min Petr Econ Geol 89:15-20

Nakajima J, Hirose F, Hasegawa A (2009) Seismotectonics beneath the Tokyo metropolitan area, Japan: effect of slab-slab contact and overlap on seismicity. J Geophys Res 114, B08309. doi:10.1029/2008JB006101

Nakajima K, Arima M (1998) Melting experiments on hydrous low-K tholeiite: implications for the genesis of tonalitic crust in the Izu-Bonin-Mariana arc. Island Arc 7:359-373

Okino K, Ohara Y, Kasuga S, Kato Y (1999) The Philippine Sea: new survey results reveal the structure and the history of the marginal basins. Geophys Res Lett 26:2287-2290

Otofuji Y, Matsuda T, Nohda S (1985) Opening mode of the Japan Sea inferred from the paleomagnetism of the Japan Arc. Nature 317:603-604

Research Group for Explosion Seismology (1986) Explosion seismic observations in Nagano and Yamanashi prefectures, central Japan, vol 61. Miyota-Shikishima 
profile. Bulletin of the Earthquake Research Institute, University of Tokyo, pp 483-501

Saito S, Arima M, Nakajima T, Misawa K, Kimura J (2007) Formation of distinct granitic magma batches by partial melting of hybrid lower crust in the Izu arc collision zone, central Japan. J Petrol 48:1761-1791

Sasatani T, Yoshii T, Ikami A, Tanada T, Nishiki T, Kato S (1990) Upper crustal structure under the central part of Japan: Miyota-Shikishima profile, vol 65. Bulletin of the Earthquake Research Institute, University of Tokyo, pp 33-48

Sato H, Hirata N, Ito K, Abe S, Iwasaki T, Koketsu K, Kato N, Hagiwara H, Ito T, Kasahara K, Kawanaka T, Ikawa T, Matsubara M, Kimura H, Okaya D (2006) Results of deep seismic profiling in the Tokyo and Kinki metropolitan areas. Earthquake source fault beneath Tokyo, Seismological Society of Japan 2006 Fall Meeting, C066, Nagoya Congress Center, 2 November 2006

Sato H, Hirata N, Koketsu K, Okaya D, Abe S, Kobayashi R, Matsubara M, Iwasaki T, Ito T, Ikawa T, Kawanaka T, Kasahara K, Harder S (2005) Earthquake source fault beneath Tokyo. Science 309:462-464

Seno T, Stein S, Gripp AE (1993) A model for the motion of the Philippine Sea plate consistent with NUVEL-1 and geological data. J Geophys Res 98:17941-17948. doi:10.1029/93JB00782

Sugimura S (1972) Plate boundaries around Japan. Kagaku 42:192-202

Suzuki H (2002) Underground geological structure beneath the Kanto Plain. Japan Rep Natl Res Inst Earth Sci Disaster Prev 63:1-19

Taira A, Tokuyama H, Soh H (1989) Accretion tectonics and evolution of Japan. In: Ben-Avraham Z (ed) The evolution of the Pacific Ocean margins. Oxford University Press, Oxford, pp 100-123

Taira A, Saito S, Aoike K, Morita S, Tokuyama H, Suyehiro K, Takahashi N, Shinohara M, Kiyokawa S, Naka J, Klaus A (1998) Nature and growth rate of the Northern Izu-Bonin (Ogasawara) arc crust and their implications for continental crust formation. Island Arc 7:395-407

Takahashi M, Saito K (1997) Miocene intra-arc bending at an arc-arc collision zone, central Japan. Island Arc 6:168-182

Tamura Y, Ishizuka O, Aoike K, Kawate S, Kawabata H, Chang Q, Saito S, Tatsumi Y, Arima M, Takahashi M, Kanamaru T, Kodaira S, Fiske RS (2010) Missing Oligocene crust of the Izu-Bonin arc: consumed or rejuvenated during collision? J Petrol 51:823-846

Tani K, Dunkley DJ, Kimura J, Wysoczanski RJ, Yamada K, Tatsumi Y (2010) Syncollisional rapid granitic magma formation in an arc-arc collision zone: evidence from the Tanzawa plutonic complex, Japan. Geology 38:215-218

Umino Y (1991) Sedimentation processes of the Kofu Basin, Yamanashi Prefecture -the feature after Tertiary age. Monogr Assoc Geol Collab Japan 38:19-25

Wessel P, Smith WHF (1998) New improved version of the generic mapping tools released. Eos Trans AGU 79:579

Willett S, Beaumont C, Fullsack P (1993) Mechanical model for the tectonics of doubly vergent compressional orogens. Geology 21:371-374

Yamanashi Prefectural Government (2002) Report on the subsurface structure investigation in 2001 fiscal year. Yamanashi Prefectural Government, Yamanashi, p 112

doi:10.1186/1880-5981-66-21

Cite this article as: Arai and Iwasaki: Crustal structure in the northwestern part of the Izu collision zone in central Japan. Earth, Planets and Space 2014 66:21.

\section{Submit your manuscript to a SpringerOpen ${ }^{\circ}$ journal and benefit from:}

- Convenient online submission

- Rigorous peer review

- Immediate publication on acceptance

- Open access: articles freely available online

- High visibility within the field

- Retaining the copyright to your article

Submit your next manuscript at $\gg$ springeropen.com 